NBER WORKING PAPER SERIES

\title{
IS THERE DISCRETION IN WAGE SETTING? \\ A TEST USING TAKEOVER LEGISLATION
}

\author{
Marianne Bertrand \\ Sendhil Mullainathan \\ Working Paper 6807 \\ http://www.nber.org/papers/w6807 \\ NATIONAL BUREAU OF ECONOMIC RESEARCH \\ 1050 Massachusetts Avenue \\ Cambridge, MA 02138 \\ November 1998
}

For extremely helpful comments, we are grateful to George Baker, Charlie Brown, Larry Katz, Caroline Minter-Hoxby, David Scharfstein, and Andrei Shleifer. We are especially indebted to Larry Katz for countless discussions. Florencio Lopez-De-Silanes and John Pound provided essential help in understanding the state takeover laws. We would also like to thank participants at the Harvard/MIT Behavioral Economics Workshop as well as the Labor/Public Finance Lunch and Organization Lunch at Harvard. This paper was written while the authors were graduate students at Harvard University. The views expressed here are those of the author and do not reflect those of the National Bureau of Economic Research.

(c) 1998 by Marianne Bertrand and Sendhil Mullainathan. All rights reserved. Short sections of text, not to exceed two paragraphs, may be quoted without explicit permission provided that full credit, including $\subset$ notice, is given to the source. 
Is There Discretion in Wage Setting?

A Test Using Takeover Legislation

Marianne Bertrand and Sendhil Mullainathan

NBER Working Paper No. 6807

November 1998

JEL No. J30, M12, G31\0

\section{ABSTRACT}

Anecdotal evidence suggests that uncontrolled managers let wages rise above competitive levels. Testing this popular perception has proven difficult, however, because independent variation in the extent of managerial discretion is needed. In this paper, we use states' passage of antitakeover legislation as a source of such independent variation. Passed in the 1980's, these laws seriously limited takeovers of firms incorporated in legislating states. Since many view hostile takeovers as an important disciplining device, these laws potentially raised managerial discretion in affected firms. If uncontrolled managers pay higher wages, we expect wages to rise following these laws. Using firm-level data, we find that relative to a control group, annual wages for firms incorporated in states passing laws did indeed rise by 1 to $2 \%$ or about $\$ 500$ per year. The findings are robust to a battery of specification checks and do not appear to be contaminated by the political economy of the laws or other sources of bias. Our results suggest that discretion significantly affects wages. They challenge standard theories of wage determination which ignore the role of managerial preferences.

Marianne Bertrand Department of Economics Princeton University Princeton, NJ 08544 and NBER mbertran@princeton.edu
Sendhil Mullainathan

Department of Economics

Massachusetts Institute of Technology

Cambridge, MA 02143

and NBER

mullain@mit.edu 


\section{Introduction}

Theorists have long recognized that the separation of ownership and control warps managerial incentives: managers neither bear the full costs of their actions nor reap the full benefits of their efforts. Costly discretion results, in which managers' personal concerns interfere with decision making. While the effects of managerial discretion on financing and product market decisions have been studied, its effects on labor market decisions are not well explored. ${ }^{1}$ Many anecdotes and newspaper articles hint that poorly controlled managers pay higher wages. When under pressure, bloated corporations trim fat by slashing wages and eliminating jobs. Successful corporate raiders often capture premiums by staring down unions into wage concessions. Even in non-unionized firms, one often hears of takeovers being followed by drastic cuts in wages and benefits. These stories depict a world in which workers' wages are influenced by managers' discretion. They are at odds with the standard views of wage determination which take managers as profit maximizing. ${ }^{2}$ In this paper, we empirically investigate whether increased managerial discretion raises worker wages.

Since wages are easily observed, what is the source of managerial discretion in setting wages? Certainly, owners know what wages are being paid to workers. On the other hand, they probably do not know what wages should be paid. While they may observe general labor supply conditions, they may not observe many of the firm-specific supply conditions. They will not have the detailed knowledge - such as quality of applicants or ease of filling positions-needed to infer the optimal wage in specific occupation-experience categories. This asymmetry of information means that owners find it difficult to judge whether wages are too high or too low. A moral hazard problem

\footnotetext{
${ }^{1}$ Some theories, such as efficiency wages, do incorporate incentive problems. But they stress the opportunism of the worker. Managers still set wages to maximize profits; they are merely constrained by the potential that workers may shirk. In other words, these theories study the influence of worker discretion on worker wages, whereas we study the influence of managerial discretion on worker wages.

${ }^{2}$ Even rent sharing models depict the wage as the splitting of quasi-rents between a worker and a profit maximizing manager.
} 
arises and equilibrium wages are distorted.

Managerial preferences determine the direction of this distortion. There are many reasons to believe that managers act as if they "prefer" high wages. First, they might care more about having high quality workers and low turnover than owners. ${ }^{3}$ Second, in a union context, they might dislike putting forth bargaining effort. Finally, they might care more than owners about improving workplace relations as they are the ones that endure the workers' complaints and enjoy the workers' company. Foulkes (1980) and Milkovich and Newman (1987) provide evidence consistent with a managerial preference for higher wages. They document that managers care about their relative position in the wage distribution and invest a considerable amount of resources in conducting complex surveys to learn about competitors' wages. A conventional wage policy consists of "leading" competitors' wages. When asked why they want to lead the wage distribution, managers sometimes mention the ability to retain workers, the ability to select from a larger applicant pool or the desire to pay fair wages. Yet, very often, managers seem to show an extreme determination to lead the wage distribution without any clear reason provided except for the desire to "be there". While evocative, such evidence can be interpreted in other ways-perhaps managers don't always know why something maximizes profits, they just know that it does-and, hence, motivates formal empirical work.

These considerations lead us to hypothesize that managerial discretion raises worker wages. Testing this hypothesis requires independent variation in the extent of the agency problem, which has traditionally been difficult to find. State anti-takeover legislation potentially provides the needed variation. Takeovers are traditionally viewed as a mechanism for disciplining wayward managers. ${ }^{4}$ Managers recognize that if they fail to maximize profits, they endanger themselves by

\footnotetext{
${ }^{3}$ Both high quality workers and low turnover will likely make the manager's job easier.

${ }^{4}$ See Manne (1965) and Jensen (1984, 1986, 1988).
} 
risking takeover and subsequent job loss. By raising the cost of takeovers, anti-takeover laws insulate managers from takeover pressures and potentially dull their incentives to maximize profits. ${ }^{5}$ These laws directly influence moral hazard and, therefore, may better proxy for managerial discretion than measures such as firm size or earnings. If managerial discretion influences wages, we expect affected firms' wages to rise with the passage of anti-takeover laws.

Using a differences-in-differences methodology, we find evidence consistent with this hypothesis. Our estimates imply that state anti-takeover laws raised average annual wages by 1 to $2 \%$ or about $\$ 500$ per year in affected firms. We include firm fixed effects and year dummies, control for observable firm characteristics, allow the impact of these characteristics to vary from year to year and control for pre-existing wage trends specific to legislating states. We further investigate the dynamics of the effect, to see whether the laws' "effect" appears before the laws. Our results are surprisingly robust to all of these specifications checks.

Is there an alternative interpretation to our findings? First, compensating differentials can easily be ruled out since they predict that the anti-takeover laws should decrease wages, not increase them. Decreased takeover fears increase job security and should lower wages. Second, one might worry that our findings are driven by managers increasing their own pay when given more discretion. However, the quantitative size of our estimates combined with the size of the firms in our sample make it very unlikely that the wage increases are restricted only to the top managers. ${ }^{6}$ Finally, in Section 7, we argue that political economy or survivorship biases likely do not contaminate our results.

\footnotetext{
${ }^{5}$ In an optimal contracting model, one would expect that shareholders would have offset some of this change by increasing the use of pay for performance incentives for managers. Bertrand and Mullainathan (1996) find evidence that CEO compensation became more sensitive to performance, relative to a control group, after the passage of the laws. But, we would not expect shareholders' reaction to completely offset the distortion. What remains is the source of our variation.

${ }^{6}$ See Section 7 for discussion.
} 
The findings in this paper are consistent with a much older institutional literature in labor economics. Both Lester (1952) and Reynolds (1951) argued that wages exhibit a "range of indeterminateness". Based on many plant visits they believed that, unlike in the simple marginal rule implied by profit maximization, managers choose from a range or band of feasible wage levels. One of the factors that Lester and Reynolds cited as generating this range of indeterminateness was managerial characteristics. They already acknowledged that owners and managers might have different goals and that the classical model can only explain a "portion of reality". To date, support for the range of indeterminateness model has been limited to the disputed findings on inter-industry wage differentials and the firm size effect. ${ }^{7}$ Our test isolates a specific mechanism-takeover pressurewhich determines a firm's position in the range of feasible wage rates.

In conclusion, this paper's main contribution is to demonstrate the impact of managerial discretion on worker wages. While the effect of managerial discretion has often been suggested, little direct evidence exists. We use the fact that anti-takeover legislation generates independent variation in the level of discretion to provide more direct evidence. Our finding that wages rise as a result of these laws supports the idea of increased discretion raising wages. They challenge standard models of wage setting, which are rooted in managerial profit maximization. ${ }^{8}$

The rest of the paper is organized as follows. Section 2 briefly discusses related empirical research. Section 3 presents the state anti-takeover laws. Section 4 describes the data. Section 5 explains the empirical methodology. We present our results in Section 6. In Section 7, we discuss alternative interpretations of our results and also describe the channels through which managerial

\footnotetext{
${ }^{7}$ For the inter-industry wage differentials literature, see Slichter (1950), Dickens and Katz (1987), and Krueger and Summers (1980). For the firm size effect, see Brown and Medoff (1989).

${ }^{8}$ Of course, we are not arguing that firm owners do not maximize profits, merely that managers may not maximize firm profits. Even when all incentive mechanisms are aligned in a profit maximizing way, managerial decisions may not be the best possible for the firm.
} 
discretion can increase workers' wages. Finally, we conclude in Section 8.

\section{Related Empirical Work}

Our work is close in spirit to the expense preference literature. Inspired by Williamson (1964), papers such as Edwards (1977) and Hannan and Mavinga (1980) have tested the idea that a more competitive environment forces management to cut frivolous expenditures. These papers typically study the banking industry, and generally find that increased product market concentration raises expenses on office space and increases employment levels. They argue that since competition reduces agency problems, this is evidence for increased discretion raising expenses. ${ }^{9}$ Heywood (1986) provides an alternative test of the expense preference theory relying on international trade. Since imports affect product market concentration, Heywood uses import penetration as a proxy for product market structure. He concentrates on the impact of import penetration on wages and finds that higher import penetration lowers wages. These papers all proxy for managerial discretion with competition, which raises two concerns. First, theory is unclear about the link between product market competition and discretion. ${ }^{10}$ Second, competition can independently affect expenses by acting through channels other than discretion. For example, Heywood (1986) himself notes that his results are also consistent with decreased union bargaining power or factor price equalization. ${ }^{11}$

An independent literature has studied the effects of ownership changes. Brown and Medoff (1988) use unemployment insurance data and find mixed effects of ownership changes on em-

\footnotetext{
${ }^{8}$ Hannan and Mavinga (1980) go further by looking at the interaction between concentration and ownership. They argue that managerial discretion requires both the absence of a strong owner and a lack of product market discipline.

${ }^{10}$ See Hart (1983) for a model where competition lowers discretion and Scharfstein (1988) for a model where competition raises discretion.

${ }^{11}$ In the banking context, increased concentration may force banks to compete on quality dimensions rather than on price dimensions (e.g. fees). Therefore, increased expenses may merely reflect this increased profit maximizing quality competition.
} 
ployment and wages. Using the Longitudinal Research Database, Lichtenberg (1992) finds that ownership changes affect white collar wages. Rosett (1990) demonstrates that union employees suffer wage losses following takeovers, though the results are not statistically significant. Gokhale, Groshen and Neumark (1995) find that takeovers flatten the wage-seniority profile and reduce employment of senior workers. While interesting in its own right, this literature has not been able to identify the impact of managerial discretion on wages. ${ }^{12}$ Since the firms under study actually change ownership, an endogeneity bias arises that makes the results hard to interpret. Changes in ownership are conditioned on past and future expected firm performance, all of which may influence wages even in the absence of managerial discretion. Similarly, a host of other factors such as quality of management and operating practices may change with ownership, which again may influence the optimal wage.

Krueger (1991) investigates the effect of ownership structure on wages by looking at the difference between franchises and company owned stores in the fast food industry. He finds that company owned stores pay higher wages and have steeper wage profiles than franchises. Since there is greater separation of ownership and control in franchises, this can be interpreted as evidence for discretion in wage setting. A complementary interpretation, preferred by Krueger, is that his findings provide evidence for efficiency wages since owner-operated stores may have a harder time monitoring workers than franchises. His data do not allow one to distinguish between these interpretations.

In summary, the literature provides only ambiguous evidence about the effects of managerial discretion on wages because it relies on indirect sources of variation in discretion, a point many of the authors recognize. ${ }^{13}$ By explicitly varying the parameters of the agency relationship, anti-

\footnotetext{
${ }^{12}$ A useful summary of this literature (along with effects of ownership changes on other variables) can be found in Bhagat, Shleifer and Vishny (1990).

${ }^{13}$ Krueger's variation is perhaps the most direct. However, the allocation of company stores between owner-operated and franchises may itself be endogenous to the characteristics of the labor market. For example, a company may prefer
} 
takeover legislation potentially provide a better estimate of the impact of discretion on wages.

\section{State Takeover Laws}

\subsection{Description}

Serious regulation of modern tender offer activity in the United States begins with the Williams Act, a federal statute passed in $1968 .^{14}$ The Williams Act provided for detailed disclosure requirements, an antifraud system, and other measures to protect target shareholders during the tender offer process. Individual states greatly extended the Williams Act by passing their own statutes in the 1970s. These are known as the "first generation" of state anti-takeover laws. The first generation laws were deemed unconstitutional by the Supreme Court in 1982 (Edgar v. Mite Corp.) primarily because of their excessive jurisdictional reach, which applied far beyond corporations chartered in the state. In response to this decision, states hesitantly began a second wave of anti-takeover statutes which dealt with some of the issues raised by the Court. To the surprise of many, these statutes were declared constitutional by the Supreme Court in 1987 (CTS v. Dynamics Corp.). ${ }^{15}$ This decision triggered a third generation of even more stringent state laws regulating takeovers.

The second and third generation statutes are of three general types: Control Share Acquisition (CSA), Fair Price (FP) and Business Combination (BC). ${ }^{16}$ In this paper, we will focus mainly on to start franchises in areas where the quality of the labor pool is on average poorer and requires more monitoring.

${ }^{14}$ Before the $1960 \mathrm{~s}$, the primary method of hostile takeover was the proxy fight which was regulated by the Securities Act of 1933 and the proxy rules of the Securities Exchange Act of 1934. Cash tender offers, however, escaped regulation until the Williams Act.

${ }^{15}$ First generation laws were declared unconstitutional because they violated the commerce clause and to a lesser extent the supremacy clause of the U.S. Constitution. The second generation laws were deemed constitutional primarily because they restricted the jurisdiction of the laws to only firms incorporated in that state. With this precedent in place, challenges to third generation laws never reached the Supreme Court, even though these laws were much more stringent in practice.

${ }^{16}$ Less common types of statutes were passed by a few states, but we do not consider them here. 
BC laws because they induced the largest change in the incentive structure faced by management. ${ }^{17}$

BCs impose a moratorium ( 3 to 5 years) on specified transactions between the target and a raider holding a specified threshold percentage of stock, unless the board votes otherwise. ${ }^{18}$ BCs impede highly leveraged takeovers, a trademark of the 1980s, since these are often financed by selling some of the target's assets. ${ }^{19} \mathrm{BC}$ laws are likely to have strong effects on disciplinary takeovers because they place in the directors' hands the right to refuse a takeover. Since incumbent management greatly influences the board, BC laws grant management a great deal of control regarding the success of takeovers. In essence, $\mathrm{BC}$ laws give management the right to "veto" a takeover. ${ }^{20}$

The legal rulings also generally reflect the idea that $\mathrm{BC}$ laws change the balance in favor of management. In Amanda Acquisition Corp. v. Universal Food Corp., a landmark case on BC legislation, the court ruled that while BCs did indeed violate management-shareholder neutrality, the Williams Act did not mandate it. Justice Schwartz, deciding on the Delaware BC law, concluded that it altered the balance of power between management and raider, "perhaps significantly." See

\footnotetext{
${ }^{17}$ Appendix Table A briefly studies the impact of the FP and CSA laws as well.

${ }^{18}$ Specified transactions include sale of assets, mergers and business relationships between raider and target. Thresholds are typically set at $10 \%$. There is, however, some state to state to variation in the thresholds but it is not important practically.

${ }^{19}$ CSAs give noninterested shareholders the right to decide whether a large shareholder has any voting rights. The acquirer of a certain threshold percentage of shares outstanding must request a vote of the non-interested shareholders and retains voting rights only if a majority of them approve. CSAs impede takeover by hindering a raider in a proxy fight. FPs require shareholders acquiring beyond a threshold level to pay a "fair price" for all stocks acquired unless the board approves otherwise. Fair prices are usually defined as some function of the highest price paid to any shareholder (for some time period) prior to the takeover announcement. FPs impede takeovers because they put limits on two tier offers commonly used by raiders.

${ }^{20}$ In contrast, in CSAs, shareholders have this "veto" right. They retain the right to block out a large shareholder since they are the ones who vote on whether a large acquirer gets voting rights. While CSAs may deter takeovers because of the transactions costs they impose, they potentially solve the collective action problems that any raider faces by forcing the shareholders to vote, in essence, on the takeover (see Grossman and Hart (1980)). Most importantly, CSA laws likely have small effects on takeovers aimed at disciplining management since it is unclear why shareholders would vote against such a move. Moreover, one technique used by entrenched management to escape takeover, avoiding a proxy vote, is now weakened. For example, "Many corporate lawyers expressed concern that control share statutes, instead of protecting against abusing takeovers, actually facilitate takeovers by providing a mechanism for a mandatory shareholder vote, which, together with the resulting publicity, provides an inexpensive and simple mechanism for putting a company into play" (Sroufe and Gelband, 1990, p. 897). FP laws, although they sometimes require both the board and shareholder approval, are more similar to the $\mathrm{BC}$ laws. We decide not to concentrate on them because previous empirical evidence show that they were relatively weak in practice. See section 3.2.
} 
Sroufe and Gelband (1990). ${ }^{21}$

\subsection{Evidence on Impact of Laws}

Anecdotal evidence on the importance of the state anti-takeover laws is plentiful. A mass of cases often followed each law where raiders attempted to argue against the law. ${ }^{22}$ This indicates that target companies understood the laws well enough to use them as defenses and that raiders felt the laws as a large enough deterrent to success to challenge them in court. Moreover, these laws received extensive coverage by both the popular press and legal practitioners.

Empirical work on the laws typically falls under two categories: studies of their impact on takeovers and studies of their impact on stock prices. Perhaps because the data are less readily available, we know of only one study that examines the impact of these laws on the number of takeovers. Hackl and Testani (1988) perform a straightforward differences-in-differences analysis for laws up to 1988 and find that these laws lessen takeover activity. States passing laws experienced approximately a $48 \%$ smaller rise in takeover attempts in this period. They also find that the proportion of takeover attempts using tender offers went down, as well as the number of tender offer attempts that were successful.

Several papers have attempted to establish the effect of these laws on stock prices. ${ }^{23}$ Most papers focus on a single law using an event study methodology. Many find negative share price

\footnotetext{
${ }^{21}$ One commentator noted that an implication of the Wisconsin decision was that "The Seventh Circuit's Amanda opinion asserts that a law, such as Wisconsin's business combination statute, can be both economic folly and constitutional" (New York Law Journal, September 14, 1989). In contrast, in the initial CTS v. Dynamics Corp. ruling on the constitutionality of CSA legislation, the court carefully weighed neutrality of the statute, concerned that the Williams act mandated shareholder management and bidder management neutrality.

${ }^{22}$ New Jersey's law, for example, was tried in Bilzerian Partners, Ltd. v. Singer Co, No. $87-4363$ (D.N.J. Dec.2, 1987). Delaware's law was immediately challenged in Black \& Decker Corp. v. American Standard Inc., 679 F. Supp. 422 (D.Del. 1988) and CRTF Corp. v. Federated Dept. Stores, Inc., 683 F. Supp. 422 (S.D.N.Y. 1988). These are only a few of the many cases revolving around these laws. Courts consistently found the laws applicable. See Matheson and Olson (1991) for more details.

${ }^{23}$ See for example, Karpoff and Malatesta (1989), Pound (1987), Szewczyk and Tsetsekos (1992), Romano (1987), Margotta et. al. (1990), Schumann (1989), and Block et. al. (1986).
} 
effects, some find insignificant negative share price effects, and some find no share price effect at all. The main difficulty is in choosing the date at which the effect of these laws should be impounded into prices since information about the legislation can be incorporated into expectations and stock prices before it is formally revealed. Some papers use dates of law passage, some use press announcements, and some use dates of law introduction. As a rule, the papers that find the most negative impacts on stock price use press announcements. ${ }^{24}$ Others use time averages of price for years after the law rather than looking for a treatment date. Choosing specific announcement dates biases coefficients towards zero because information about passage might have leaked out before the passage and expectations about passage might already be incorporated into prices. Using time averages, on the other hand, reduces power because of the high variability of stock prices. For us, the problem of choosing a treatment date is less problematic since wages are reported and decided upon on an annual basis.

Easterbrook and Fischel (1991) summarize the literature on stock price reactions up to that point. They argue that on average the value of firms covered by these laws fell by $.5 \%$. In dollar terms, these are quite large losses. Applied to the entire New York Stock Exchange, they imply a loss of $\$ 10$ to $\$ 20$ billion dollars. ${ }^{25}$ Karpoff and Malatesta (1989) examine stock price reactions to all laws passed before 1987 . They choose the effective date to be the first date on which they find a press announcement for the law. Their study is useful because they comprehensively analyze each type of law. They find significant negative reactions to the passage of $\mathrm{BCs}$, resulting in a loss of value of approximately $.467 \%$. They find less negative $(-.274 \%)$ and insignificant responses to FPs. Finally, they find no reaction to the adoption of CSAs. The result of their study conforms

\footnotetext{
${ }^{24}$ See Karpoff and Malatesta (1989), Pound (1987), and Szewczyk and Tsetsekos (1992).

${ }^{25}$ Moreover, Easterbrook and Fischel likely underestimate the effect for our purposes since we focus on BC laws rather than all laws.
} 
well to a priori reasoning and reinforces our belief that a focus $\mathrm{BC}$ laws is a natural choice for our study.

\section{Data}

In order to determine which firms are affected by anti-takeover legislation, we must know each firm's state of incorporation. This leads us to use COMPUSTAT data, one of the few data sources which include both labor data and corporate variables such as state of incorporation. COMPUSTAT reports financial variables for more than 7500 individual corporations established in the U.S. (and territories) since 1976. The data are drawn from annual reports, $10-\mathrm{K}$ filings and 10-Q filings, and samples large companies with substantial public ownership.

The state of incorporation we have available for each company is the state of incorporation in 1995. ${ }^{26}$ For all other variables, we use all data available between 1976 and 1995 . Since the laws were passed in the middle and late 1980s, this gives us several years before and after the laws.

The labor data provided by COMPUSTAT are aggregate with no direct wage measure reported. Instead, we compute wages using the labor expenses and employment data. Labor expenses include salaries, wages, pension costs, profit sharing, incentive compensation, payroll taxes and other employee benefits; they exclude commissions. Employment is defined as the number of company workers as reported to shareholders in annual reports. It is reported by some firms as an average number of employees over the year and by others as the number of employees at the end of the year; it includes part-time and seasonal employees; it excludes contract workers, consultants and employees of unconsolidated subsidiaries. We build the wage measure by dividing labor expenses

\footnotetext{
${ }^{26}$ Ideally, we would like to use state of incorporation at some time before the laws were passed, but we only have available to us the state of incorporation in 1995. Anecdotal evidence indicates that changes in state of incorporation were rare, especially for the very large companies in our sample. Romano (1993) discusses some of these issues.
} 
by reported employment.

The resulting labor data are extremely spotty both across firms and time. Many firms report no labor data and some report it only intermittently. More importantly, there are large outliers when one computes firm by firm annual growth rates of wages. ${ }^{27}$ While our results are unaffected by the inclusion of these outliers, we are uncomfortable using these data points. Hence, we decide to exclude from most of our regressions firms that at any point display aberrant wage changes. Specifically, we drop any firm $i$ for which there exists a period $t$ during which the ratio $\frac{w_{t+1}}{w_{t}}$ is greater than $\frac{7}{4}$ or less than $\frac{4}{7}$. Practically, this results in excluding firms for which at any point in time the wage growth rate is unreasonably positive (more than $75 \%$ ) or unreasonably negative (less than $-44 \%$ ). This exclusion rule leads to a loss of 547 firm-year observations. Table 3 demonstrates that our results are insensitive to the use of this specific exclusion rule.

Our final sample consists of 877 firms over the period 1976-1995 and of 9305 firm-year cells. It consists of all the firms ever in existence during the sample period, for whom we can compute wage data for every year they are in existence, and whose wage growth does not exhibit outliers. It thus includes firms that disappeared from COMPUSTAT before 1995 as well as firms that appeared in COMPUSTAT after $1976 .^{28}$ Since the full COMPUSTAT sample over this time period has 49,474 firm-year cells, our dataset represents approximately $18.8 \%$ of the full sample. ${ }^{29}$

\footnotetext{
${ }^{27}$ While the mean growth rate of wages is $2 \%$ and the median growth rate is $1 \%$, the bottom one percentile of the distribution has wage growth rates below $-30 \%$ and the top one percentile has wage growth rates above $46 \%$.

${ }^{28} \mathrm{~A}$ firm being taken over disappears from COMPUSTAT while the acquiring firm appears in our sample as having grown. Similarly, a merger that results in a whole new firm leads to two firms leaving the sample and a new firm entering it.

${ }^{29} \mathrm{By}$ the full COMPUSTAT sample we mean firms which report state of incorporation and are incorporated in the U.S. We cannot use all these firms since many do not report labor data. Our sample is a larger proportion of firm-year observations than of firms because larger (and hence longer lasting) firms are more likely to report labor expenses.
} 


\subsection{Summary Statistics}

Table 1 presents means of the variables of interest. In columns 1 and 2, we compare the full COMPUSTAT sample to our sample. Columns 3 and 4 compare, within our sample, treatment group (firms incorporated in states that pass BC laws at some point) and control group (firms incorporated in states that never pass BC laws). Wages are expressed in thousands of dollars, and employment in thousands of employees. Assets is total assets (current assets plus net property, plant and equipment plus other non-current assets) in millions of dollars. Sales is net sales (gross sales reduced by cash discounts, trade discounts, returned sales and allowances for which credit is given to customers) in millions of dollars. Market value is the end of year stock market value of the firm in millions of dollars. Wages, assets, sales and market value are deflated using the CPI $(1983-1984=100)$.

As one can see by comparing columns 1 and 2 the firms in our sample are significantly larger on average than the firms in the full sample. ${ }^{30}$ The next two columns allow us to compare firms incorporated in states passing BC legislation and those in states not passing BC legislation. First, one will note that many of the firms in our sample are located in states passing BC laws. ${ }^{31}$ However, as we explain more carefully in section 5 , this does not cause our effective control group to be small. Since the states staggered their passage of laws, the effective control group for any given year is the set of states not passing laws that year. Second, firms passing BC legislation appear slightly larger on all dimensions. Because we use firms fixed effects, our empirical methodology allows us to deal with any fixed difference between treatment and control firms. Other problems potentially arise from time-varying differences between treatment and control firms that are correlated with

\footnotetext{
${ }^{30}$ Virtually all of this difference arises from dropping firms with no wage data rather than dropping firms with aberrant wage data. This is to be expected since the aberrant wage changes results in a loss of only 500 or so firm-year observations.

${ }^{31}$ Table 2 gives the list of state and year of enactment for $\mathrm{BC}$ legislation.
} 
the passage of the laws. We discuss how we deal with these problems in the next section.

\section{Empirical Methodology}

We implement our test using a differences-in-differences methodology. By analogy with the experimental terminology, we refer to states passing anti-takeover legislation as treatment states and to firms incorporated in those states as treatment firms. Similarly, we refer to states not passing anti-takeover legislation and firms incorporated in those states as control states and control firms respectively. In the first level of differences, we subtract wages $w$ before the law from wages after the law. Since we can do this for both control and treatment, we get two sets of differences: $\Delta^{T} w$ for the treatment group and $\Delta^{C} w$ for the control group. By itself, $\Delta^{T} w$ could be a misleading estimator of the laws' impact since other changes contemporaneous with the laws affect this estimate. To deal with this, we introduce a second level of differences. If contemporaneous shocks affect treatment and control groups in roughly similar ways, then those shocks should also be contained in $\Delta^{C} w$. One can therefore subtract $\Delta^{C} w$ from the first difference $\Delta^{T} w$ to estimate the effect of the law.

This approach can be easily understood with an example. Suppose we wish to estimate the effect of the Pennsylvania law passed in 1989. We would subtract wages after 1989 from wages before 1989 for the Pennsylvania firms. However, other things in 1989 , such as a recession, may have affected Pennsylvania firms. Choosing a control state, for example New Jersey, would help control for changing economic conditions. If New Jersey firms were also subject to this recession, the change in their wages would be a measure of its severity. We would, therefore, compare the difference in wages in Pennsylvania before and after 1989, to the difference in wages in New Jersey 
before and after 1989. The difference of those two differences would serve as the estimate of the law's effect in Pennsylvania.

In practice, we implement this approach in a regression framework in order to control for changes in observables:

$$
w_{i t}=a+b X_{i t}+c B C_{i}+d A f \operatorname{ter}_{t}+\delta B C_{i} * A f \operatorname{ter}_{t}+\epsilon_{i t}
$$

where $i$ indexes firms, $t$ indexes time, $w_{i t}$ is log wage, $X_{i t}$ are controls, $B C_{i}$ is a dummy variable for treatment firm ( $B C_{i}$ equals 1 if firm $i$ is incorporated in a state that passes a BC law), After

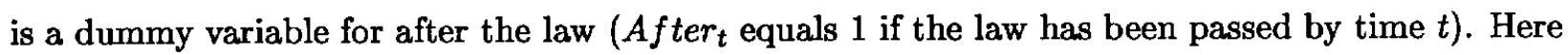
$B C_{i}$ and $A f t e r_{t}$ respectively pick up any fixed difference between treatment and control and any common shock contemporaneous with the law. ${ }^{32}$ Our estimate of the law's effect is $\delta$, the coefficient on the interaction term: change in outcomes at the time of the legislation specific to states passing the legislation.

Two issues need to be addressed before estimating this regression. First, equation 1 does not fully exploit the panel nature of our data set. ${ }^{33}$ Second, by assuming a common After $_{t}$ dummy across firms, we restrict ourselves to laws passed in the same year. In practice, the laws were passed in different years. To deal with the first issue, we extend the specification to include firm fixed effects. To deal with the second, we allow for laws to be passed at different times. The noninteracted After $t_{t}$ dummy, therefore, is replaced by a set of $A f t e r_{t}$ dummies, one for each year in which a law is passed. More generally, we include year dummies for all the years to better control for aggregate conditions. Finally, since each firm faces a different treatment date, the After $_{t}$ dummy in the interaction term is replaced by a firm specific After $_{i t}$ dummy:

$$
w_{i t}=\alpha_{t}+\beta_{i}+\gamma X_{i t}+\delta B C_{i} * A f t e r_{i t}+\epsilon_{i t}
$$

\footnotetext{
${ }^{32}$ In practice, After ${ }_{t}$ allows for a one year delay in the law's effect. This allows for lags in implementation as well as the fact that the data may reflect values from the previous calendar year.

${ }^{33}$ See Section 4.
} 
where $w_{i t}$ and $X_{i t}$ are defined as above, $\alpha_{t}$ are year fixed effects, $\beta_{i}$ are firm fixed effects and After $_{i t}$ is a dummy variable that equals 1 if the law has been passed by time $t$ in firm $i$ 's state of incorporation. Note that we have dropped $B C_{i}$ as a control because the firm fixed effect makes it redundant. One important implication of staggered passage dates is that we no longer need our control group to be states that do not pass laws. The above specification can be estimated even if all states eventually passed a law. It implicitly takes all firms incorporated in states not passing a law at time $t$ as the control group for a law passed at time $t$, even if they have already passed one or will pass one later. While almost every large state eventually adopts a BC law (California and Texas being the most notable exceptions), they adopt it at different times. For a list of state and year of enactment for the laws, see Table 2.

Two major difficulties arise with any differences-in-differences estimator: (i) shocks differentially affecting the treatment group contemporaneous with the law will pollute the estimates and (ii) the passage of laws at time $t$ may be correlated with the error term in $t+j$, where $j \geq 0$. The first difficulty is especially severe when treatment and control groups are different on important dimensions. Shocks affecting those dimensions will then differentially affect treatment and control groups. For example, if treatment firms were larger, shocks affecting large firms' wages would affect treatment firms more than control firms. If by chance these shocks happen at the same time as the laws, the estimated effect of the laws would be biased. To deal with this, we allow the coefficients on a variety of observable characteristics to be different for each year. This amounts to allowing $\gamma$ to vary by year. Suppose our results were driven merely by contemporaneous shocks to large firms, of which the treatment group has more. In this case, our estimates are merely picking up on the time-varying effects of size. By directly allowing the coefficient on size to vary by time, we can control for these contemporaneous shocks. In practice, when we allow for the coefficients on 
all observables to vary over time, we will find that our estimates of the effect of the BC laws on workers' wages do not change.

The second difficulty arises from the political economy of these laws. For example, Besley and Case (1994) have argued that basing tests on state legislation can bias results since passage of laws is often correlated with current and future economic outcomes. In Section 7, we present two pieces of evidence that suggest that such "political economy bias" does not drive our results.

\section{Results}

\subsection{Basic Results}

Table 3 presents various estimations of equation 2. Each specification contains year dummies and firm fixed effects. In columns 2, 4, 6 and 7, we further control for log assets, log employment, $\log$ sales and $\log$ market value. Columns 1 and 2 use the entire set of firm-year cells for which we were able to compute a wage measure. In columns 3 to 7 , we exclude firms whose wages grow too much or drop too much at any point in time. In columns 3 and 4 , we use growth rates of $\frac{7}{4}$ and

$\frac{4}{7}$ as thresholds. Columns 5 and 6 uses $\frac{3}{2}$ and $\frac{2}{3}$ as thresholds. Column 7 replicates column 4 , but excludes firms incorporated in Delaware from the sample.

Before discussing the effect of the BC laws, let's first briefly review the other determinants of log wage. While log assets and log sales are positively correlated with log wage, log market value does not appear to additionally influence wages. In all specifications, we find a strong negative sign on $\log$ employment. The coefficients on those four determinants of firm size are such that a doubling of the size of a firm leads to a 2 to $3 \%$ decrease in wages. This seems at odds with the standard firm size-wage effect where larger firms appear to pay higher wages. However, the strong negative 
correlation between wages and employment is very likely caused by measurement error. Since the wage measure is defined as labor expenses divided by employment, any measurement error in the employment variable will show up in the wage variable, and will negatively bias the employment coefficient. In regressions that are not reported here, we have instrumented log employment with the lagged value of log employment in order to reduce measurement error. We have found that the employment coefficient stays negative but is about 50 to $60 \%$ smaller in absolute value. The firm size-wage effect implied by the instrumental variables estimation is such that a doubling of the size of a firm increases wages by about $1 \%$.

In the first six columns, we find a consistent $1 \%$ to $1.7 \%$ increase in wages due to the passage of the laws. The estimates become more precise as we exclude more of the aberrant wage data, although the mean effect does not change much. The addition of controls in columns 2,4 and 6 does not qualitatively alter the estimated coefficient. ${ }^{34}$

One might be concerned that firms incorporated in Delaware drive our finding of a positive and significant effect of $\mathrm{BC}$ legislation on wages. Indeed, more than a third of the firms in our sample are incorporated in Delaware. In column 7, we replicate column 4 but with Delaware firms excluded from the sample. The estimated treatment effect stays significant, and the point estimate is actually larger than in column 4. This result is in concordance with Romano's extensive analysis of state anti-takeover laws. Romano (1993) claims that the BC statute in Delaware was relatively weak compared to other states.

Table A in the Appendix briefly examines the impact of the two other major anti-takeover statutes on wages: FP and CSA. The results confirm our analysis in Sections 3.1 and 3.2. Column 2 shows that FP statutes have a (small) positive but insignificant impact on wages. CSA statutes

\footnotetext{
${ }^{34}$ We also estimated these regressions using employment as a dependent variable. We found no significant effect of the passage of the $\mathrm{BC}$ laws on the employment measure.
} 
do not appear to have any impact on wages (column 3). In addition, the impact of FP statute and CSA statute on wages is statistically and economically insignificant once we control for the impact of the BC statute (column 4). This reflects the fact that many states passing CSA or FP statutes later passed BC laws.

\subsection{Robustness Checks}

An important assumption of the differences-in-differences methodology is that shocks contemporaneous with the laws affect treatment and control groups similarly. This assumption can be problematic if the treatment and control groups are dissimilar on observable (and potentially unobservable) characteristics. As we have seen in Table 1, the set of firms incorporated in states passing $\mathrm{BC}$ laws are larger in every size dimension (market value, sales, assets and, to a lesser extent, employment). Since states pass laws at different times, this is less of a problem. BC states themselves serve as controls for all states that pass laws at different times. Nevertheless, one worries that shocks contemporaneous with the law that differentially affect large firms may still corrupt our estimates.

Columns 1 to 4 of Table 4 attempt to deal with this problem. We allow the returns to assets, employment, sales and market value to change over time. That is, we allow a different coefficient on these covariates for each single year. Suppose that an aggregate shock raised wages in large firms. As the treatment firms are larger, if this shock coincided with the passage of some of the laws, our estimate of the effect of the BC legislation would be biased. Part of the estimated treatment effect would indeed come from this shock. Allowing covariates to vary by time controls for any such shock. If shocks to any of these observables contemporaneous with the laws corrupt our results, we expect the coefficient on the treatment variable to significantly drop. Comparing columns 1 to 
4 in Table 4 to column 4 in Table 3, we see that our estimate of the effect of the BC laws remains virtually unchanged.

Column 5 of Table 4 deals with a related issue: pre-existing trends. The differences-in-differences estimate will also be corrupted if wages in the $\mathrm{BC}$ group were following a different trend than wages in the non-BC group. This concern is again lessened by the staggering of laws. Nevertheless, we deal with this problem directly in column 5 by allowing for a different trend term for the $\mathrm{BC}$ and non-BC firms. As one can see, our results are not affected by this inclusion. ${ }^{35}$ In column 6 , we cumulate all the previous specification checks by including a treatment trend and allowing the returns to all covariates to vary over time. Again, the results stay the same.

\subsection{Distribution of Treatment Effect}

The results in the previous sections have established the mean effect of BC laws. One is also interested in the distribution of this effect. Table 5 addresses this issue by interacting the $B C_{i} *$ After $_{i t}$ term with firm level characteristics. We also allow the coefficient on the relevant firm characteristic to vary by year and by $B C$ and non- $B C$ firms. To make the coefficient on the direct $B C_{i} *$ After $_{i t}$ term easier to interpret, we have demeaned each of the firm level characteristics. Therefore, the coefficient on $B C_{i} *$ After $r_{i t}$ represents the effect of BC laws for a firm of average size. As the results in Table 5 indicate, larger firms appear to have bigger wage increases after the passage of the anti-takeover laws.

A priori reasoning does not give much assistance in determining whether wages in large firms should be more or less affected by anti-takeover legislation than wages in small firms. On the one hand, larger firms may have more dispersed ownership making takeovers a more important

\footnotetext{
${ }^{35}$ The coefficient on the pre-existing trend term for BC states is small and insignificant.
} 
disciplining device, so the effect on wages should be bigger. On the other hand, the takeover of larger firms may in general be harder since it requires more capital, so the effect on wages should be smaller. Our empirical findings support the first story.

\subsection{Treatment Dynamics}

In the previous section, we investigated how the effect of the passage of the $\mathrm{BC}$ laws was distributed across firms. In Table 6, we investigate how the effect is distributed over time. We estimate the following regression:

$$
\log \left(w_{i t}\right)=\alpha_{t}+\beta_{i}+\gamma X_{i t}+\delta B C_{i} * \text { After }_{i t}+\delta_{0} B C_{i} * \text { Before }_{i t}^{0}+\delta_{-1} B C_{i} * \text { Before }_{i t}^{-1}+\epsilon_{i t}
$$

which includes two Before $_{i t}$ terms to capture leads. Befor $e_{i t}^{0}$ is a dummy for the year the law passed and Before $_{i t}^{-1}$ is a dummy for the year before the law passed. In Table 6, we also break apart the After $_{i t}$ dummy into dynamic terms where $A f t e r_{i t}^{s}$ refers to a dummy for $s$ years after the law and $A$ fter ${ }_{i t}^{\text {s }}$ refers to a dummy that is one if the law was passed strictly more than s years ago.

In column 1, we investigate the effects of the law, 1 year after, 2 years after and more than 2 years after the law. We find that most of the law's effects are in the third and later years. In column 2, we look for evidence of an effect the year the law was passed and the year before the passage of the law. This serves as a useful consistency check. It is comforting that we find no significant effect before or contemporaneous with the laws passage. ${ }^{36}$ Finally, in column 3 , we estimate the full regression allowing for effects before and year by year after. The results are consistent with our findings in columns 1 and 2 .

\footnotetext{
${ }^{36}$ See Section 7 for more on this.
} 


\section{Interpretation}

What can explain our findings? We can easily dismiss a compensating differentials interpretation. The theory of compensating differentials predicts that anti-takeover legislation, by decreasing takeover fear, reduces the fear of job loss and should therefore lower, and not raise, workers' wages. One might also worry that the increased labor expenses are isolated to top management and reflect a stronger skimming ability for that group when ownership is weaker. It is important to keep in mind, however, that our sample is composed of very large firms. Hence, top management typically represents only a minuscule proportion of total employment in those firms. Even very large salary changes at the top could not significantly move labor expenses. We find, however, a more than $1 \%$ increase in per employee wage. ${ }^{37}$

Up to this point, we have taken the anti-takeover laws as exogenous. In practice, they might be the result of changing economic conditions and such changes may be correlated with workers' wages. For example, if states with rising wages (or those expecting wages to rise) passed antitakeover legislation, then the estimated effect will be biased upward. We present two pieces of evidence suggesting that this is not the case. First, if underlying trends in wages give rise to these laws, we expect our estimates to drop when we explicitly allow for such trends in legislating states. As we saw in columns 5 and 6 of Table 4, the estimated treatment effect hardly changes when we include a treatment trend. Second, if short term changes in economic conditions give rise to the anti-takeover laws, we might expect to find some "effect" of the laws prior to passage. In columns 2 and 3 of Table 6 , we included lead dummies for the year the law passed and the year before the

\footnotetext{
${ }^{37}$ Bertrand and Mullainathan (1997) investigate the effects of this legislation on CEO pay and find that CEO compensation increases by about $5 \%$ following the passage of the $\mathrm{BC}$ laws. The mean wage in our sample is about $\$ 30,000$ and the mean employment is about 19,000 . A (lower bound) $1 \%$ pay raise represents $\$ 300$ per worker or $\$ 5,700,000$ per year for the mean firm. A $5 \%$ increase in pay for the CEO could not account for this.
} 
law passed. Neither of the lead dummies was ever significant. These two tests suggest that our results are not driven by political economy biases.

A similar but alternative explanation for our results can come from a survivorship bias induced by the raw effect of the laws on the number of takeovers. Suppose takeovers are more likely to occur in high wage growth firms. Then, these laws reduce takeovers and therefore increase the relative number of high wage growth firms. ${ }^{38}$ Therefore, mean wage rises not through the diminished threat but through the reduction of the actual number of takeovers. Thus our results might be driven by a reduction in the actual probability of takeover after the passage of the laws. We feel that this explanation is not very relevant because actual takeovers are very rare events. Even if these laws completely eliminated takeovers, wage growth in firms taken over would have to be significantly higher than average wage growth in order to explain the $1-2 \%$ wage effect.

We also feel confident in ruling out an efficiency wage interpretation of our result. Under an efficiency wage story, the increase in workers' wages could be regarded as owners' optimal response to a decrease in the level of monitoring by managers after the anti-takeover laws. While theoretically possible, this story is totally at odds with the institutional details of human resource practices in large firms. It requires that owners (shareholders) control worker wages, a practice unheard of in large public corporations. ${ }^{39}$

At this point, we feel that we can reasonably assert that managerial discretion is likely responsible for at least some of the wage increase. One can think of different specific models through which

\footnotetext{
${ }^{38}$ If takeovers were merely eliminating high wage firms and not high wage growth firms, this would be dealt with by the inclusion of fixed effects.

${ }^{39}$ See, for example, Foulkes (1980) and Milkovich and Newman (1987). One may wonder why the question of discretion in wage setting is interesting if it is clear that managers have complete control over the wage setting process. The key empirical question in this paper is whether managers exercise this control in a profit maximizing way or in a self-serving way. Even when managers have complete control, forces (such as incentive schemes) may make them behave in a profit maximizing way for all practical purposes. Thus, the question of whether discretion distorts wages is an empirical one.
} 
managerial discretion operates. First, it could be that every worker in the firm gets a $1-2 \%$ wage increase. Second, it could be that the worker quality pool increases, raising mean wages. Managers may choose an excessive level of quality, for example to minimize their private cost of providing training. In that case, managers may not have direct preferences for paying higher wages. Rather, their utility directly increases with the quality of the labor force and thus indirectly increases with workers' wages. From the owner's viewpoint both models result in a profit loss, though the second will result in a proportionately smaller loss. ${ }^{40}$

Third, Shleifer and Summers (1988) provide a dynamic version of the managerial discretion story that also implies an increase in wages. In their model, workers make non-contractible investments in firm-specific human capital and managers sign implicit contracts to compensate workers for these investments. The quasi-rents generated by the investments create a time-consistency problem. Since these investments are sunk, wages can be cut ex post and workers never renumerated for their investment. They argue that incumbent managers are more likely to honor implicit contracts to repay workers than outsiders or owners are. This assumption is a dynamic equivalent of our (static) assumption that managers prefer to pay higher wages. Thus in their theory, managerial discretion raises worker wages because managers have a preference for honoring the existing implicit contracts. This preference then induces human capital investments which raise wages. In this case, managerial discretion enhances shareholder wealth because it solves the time-inconsistency problem.

We can attempt to discriminate between the pure rent story (story 1) and the other stories (2 and 3) by comparing the quantitative impact of the laws on shareholder value with the quantitative impact on wages. The average stock price reaction to these laws (about $-.5 \%$ according to Easterbrook and Fischel) does not appear large enough to explain a 1 to $2 \%$ pure increase in labor

\footnotetext{
${ }^{40}$ If higher wages are pure rents, profits go down dollar for dollar. If they are increased quality, some of the profits lost in wages will be recouped by the increased productivity.
} 
cost. Assuming that labor costs are about four times profits, a permanent 1 to $2 \%$ increase in wage will imply a 4 to $8 \%$ drop in profits. Yet, as we mentioned earlier, event study estimates of the stock price reaction to the laws are likely to be biased towards zero given the difficulty of picking a specific announcement date. Also, because it covers all types of laws (CSAs, FPs, and BCs), the average effect reported by Easterbrook and Fischel is likely to underestimate the true stock price effect for our sample of firms and experiment. We have indeed previously argued that the BC laws had the largest impact. With these caveats in mind, we conclude that while increased managerial discretion must have caused some rent dissipation, it also likely increased the worker quality pool or deterred breach of trust, thereby encouraging human capital investment by workers.

\section{Conclusion}

State anti-takeover legislation provides plausibly exogenous variation in the degree of the agency problem. We have used this variation to test for the effect of managerial discretion on wages. Using a differences-in-differences approach, we have demonstrated that wages rose following these laws. Our results support many previously untested popular perceptions about the preference of managers for paying high wages. Since larger firms are more likely to be publicly owned and in general have more dispersed ownership, these results also suggest that the firm size-wage effect may partly reflect a managerial discretion effect. ${ }^{41}$

The findings in this paper depict a wage setting process that implies, to use Reynolds' (1951) term, a "range of indeterminateness." Moral hazard between managers and owners means that wages will reflect the diversity of managerial preferences and discretion. In that sense, this paper

\footnotetext{
${ }^{41}$ Various studies have found that larger firms pay higher wages, even after controlling for worker or plant characteristics. See Lester (1967) and Brown and Medoff (1989).
} 
presents a serious challenge to standard models of wage determination, all of which posit managerial profit maximization. 


\section{References}

Auerbach, Alan J., ed. Corporate Takeovers: Causes and Consequences. Chicago: University of Chicago Press, 1988.

Bertrand, Marianne, and Mullainathan, Sendhil. "Executive Compensation and Incentives: The Impact of Takeover Legislation." Mimeo (1997). Cambridge, MA: Harvard University.

Besley, Timothy, and Case, Ann. "Unnatural Experiments? Estimating the Incidence of Endogenous Policies." Working Paper no. 4956 (1994). Cambridge, MA: National Bureau of Economic Research.

Bhagat, Sanjai, Shleifer, Andrei, and Vishny, Robert. "Hostile Takeovers in the 1980s: The Return to Corporate Specialization." Brookings Papers on Economic Activity. Special issue (1990): 1-72.

Block, Dennis, Barton, Nancy and Roth, Andrea. "State Takeover Statutes: The 'Second Generation'." Securities Regulation Law Journal. 13 (1986): 332-355.

Brown, Charles, and Medoff, James. "The Impact of Firm Acquisitions on Labor." In Auerbach (1988).

Brown, Charles, and Medoff, James. "The Employer Size-Wage Effect." Journal of Political Economy. 97 (1989): 1003-1015.

Dickens, William, and Lawrence Katz. "Inter-Industry Wage Differences and Theories of Wage Determination." Working Paper no. 2271 (1987). Cambridge, MA: National Bureau of Economic Research.

Easterbrook, Frank, and Fischel, Daniel. The Economic Structure of Corporate Law. Cambridge, MA: Harvard University Press, 1991.

Edwards, Franklin R. "Managerial Objectives in Regulated Industries: Expense-Preference Behavior in Banking." Journal of Political Economy. 85 (1977): 147-162.

Foulkes, Fred. Personel Policies in Large Non-Union Firms. Englewood Cliffs, NJ: Prentice-Hall, 1980.

Gokhale, Jagadeesh, Groshen, Erica, and Neumark, David. "Do Hostile Takeovers Reduce Extramarginal Wage Payments?" Review of Economics and Statistics. 77 (1995): 470-485.

Hackl, Jo, and Testani, Rosa. "Second Generation State Takeover Statutes and Shareholder Wealth: An Empirical Study." The Yale Law Journal. 97 (1988): 1193-1231.

Hart, Oliver. "The Market Mechanism as an Incentive Scheme." Bell Journal of Economics. 14 (1983): 185-216.

Hannan, Timothy, and Mavinga, Ferdinand. "Expense Preference and Managerial Control: The Case of the Banking Firm." Bell Journal of Economics. 11 (1980): 671-682.

Heywood, Jonathan. Product Market Structure and the Labor Market. Ph.D. Dissertation (1986). Ann Harbor, MI: University of Michigan. 
Jensen, Michael. "Takeovers: Folklore and Science." Harvard Business Review. 84 (1984): 109-121.

Jensen, Michael. "Agency Costs of Free Cash Flow, Corporate Finance, and Takeovers." American Economic Review. 76 (1986): 323-329.

Jensen, Michael. "Takeovers: Their Causes and Consequences," Journal of Economic Perspectives. 2 (1988): 21-48.

Karpoff, Jonathan, and Malatesta, Paul. "The Wealth Effects of Second-Generation State Takeover Legislation." Journal of Financial Economics. 25 (1989): 291-322.

Krueger, Alan. "Ownership, Agency, and Wages: An Examination of Franchising in the Fast Food Industry." Quarterly Journal of Economics. 106 (1991): 75-101.

Krueger, Alan, and Lawrence Summers. "Efficiency Wages and the Inter-Industry Wage Structure." Econometrica. 56 (1988): 259-293.

Lester, Richard. "Pay differentials by Size of Establishment". Industrial Relations. 7 (1967): 57-67. Lester, Richard. "A Range Theory of Wage Differentials." Industrial and Labor Relations Review. 5 (1952): 483-500.

Lichtenberg, Frank. Corporate Takeovers and Productivity. Cambridge, MA: MIT Press, 1992.

Manne, Henry. "Mergers and the Market for Corporate Control". Journal of Political Economy. 73 (1965): 110-120.

Margotta, Donald G., McWilliams, Thomas, and McWilliams, Victoria. "An Analysis of the Stock Prices Effect of the 1986 Ohio Takeover Legislation". Journal of Law, Economics and Organization. 6 (1990): 235-251.

Matheson, John and Olson, Brent. "Shareholder Rights and Legislative Wrongs: Toward Balanced Takeover Legislation." The George Washington Law Review. 59 (1991): 1425-1524.

Milkovich, George, and Newman, Jerry. Compensation. Plato, TX: Business Publications, 1987.

Pound, John. "The Effects of Antitakeover Amendments on Takeover Activity: Some Direct Evidence". Journal of Law and Economics. 30 (1987): 353-367.

Reynolds, Lloyd. The Structure of Labor Markets: Wages and Labor Mobility in Theory and Practice. New York, NY: Harper \& Bros., 1951.

Romano, Roberta. "Competition for Corporate Charters and the Lesson of Takeover Statutes." Fordham Law Review. 61 (1993): 843-864.

Romano, Roberta. "The Political Economy of Takeover Statutes." Virginia Law Review. 73 (1987): 111-199.

Rosett, Joshua. "Do Union Wealth Concessions Explain Takeover Premiums? The Evidence on Contract Wages." Journal of Financial Economics. 27 (1990): 263-82.

Scharfstein, David. "Product-Market Competition and Managerial Slack." Rand Journal of Economics. 19 (1988): 147-155.

Schumann, Laurence. "State Regulation of Takeovers and Shareholder Wealth: The Case of New York's 1985 Takeover Statutes." Rand Journal of Economics. 19 (1988): 557-567. 
Shleifer, Andrei and Summers, Lawrence. "Breach of Trust in Hostile Takeovers." In Auerbach (1988).

Slichter, Sumner. "Notes on the Structure of Wages." Review of Economics and Statistics. 32 (1950): 80-91.

Sroufe, Evelyn, and Gelband, Catherine. "Business Combination Statutes: A "Meaningful" Opportunity For Success?" The Business Lawyer. 45 (1990): 890-921.

Szewczyk, Samuel and Tsetsekos, George. "State Intervention in the Market for Corporate Control: The Case of Pennsylvania Senate Bill 1310." Journal of Financial Economics. 31 (1992): 3-23.

Williamson, Oliver. The Economics of Discretionary Behavior: Managerial Objectives in a Theory of the Firm. Englewood Cliffs, NJ: Prentice Hall, 1964. 


\begin{tabular}{lcccc}
\hline \multicolumn{5}{c}{ Table 1: Summary Statistics } \\
& FULL & SAMPLE & BC & No BC \\
& & & & \\
Log Wage & - & 3.293 & 3.312 & 3.254 \\
& & $(.429)$ & $(.465)$ & $(.344)$ \\
Log Employment & .760 & 1.681 & 1.308 & 1.307 \\
& $(2.006)$ & $(1.703)$ & $(1.690)$ & $(1.702)$ \\
& & & & \\
Log Assets & 5.692 & 7.344 & 7.554 & 6.936 \\
& $(2.057)$ & $(1.814)$ & $(1.787)$ & $(1.798)$ \\
Log Market Value & 4.816 & 5.980 & 6.159 & 5.630 \\
& $(1.904)$ & $(1.693)$ & $(1.651)$ & $(1.721)$ \\
Log Sales & & & & \\
& 5.313 & 6.420 & 6.546 & 6.174 \\
Sample Size & $(2.041)$ & $(1.686)$ & $(1.668)$ & $(1.692)$ \\
& 49474 & 9305 & 6139 & 3166
\end{tabular}

Notes:

1. Source: COMPUSTAT, 1976-1995. Wages are defined as annual labor expenses divided by employment. Labor expenses is in millions; assets is the total start of year assets in millions; employment is total employment in thousands; sales is net sales in millions; market value is the market value of the firm in millions. Wages, assets, market value and sales are deflated using the CPI (International Financial Statistics,1996) (1983-1984=100).

2. FULL is the set of firm-year observations in COMPUSTAT for firms with nonmissing state or country of incorporation and incorporated in the U.S. SAMPLE is the set of firm-year observations in FULL for which wage data are available; it only includes firms for which the annual wage growth rate is always below $75 \%$ and always over $-44 \%$. BC and No BC are the set of firm-year obervations in SAMPLE with firms incorporated in states passing a business combination statute and no business combination statute respectively.

3. Standard deviations are in parenthesis.

4. Sample Size is the number of firm-year observations in sample for which at least one of the variables in list is available. Because market value and sales are missing for a few firm-year observations, the number of firm-year observations in SAMPLE for which all variables in list are available is 9108 . 
Table 2: State Anti-Takeover Legislation: Dates of Enactment of Business Combination Laws ${ }^{a}$

Arizona (1987)

Connecticut (1989)

Delaware (1988)

Georgia (1988)

Idaho (1988)

Illinois (1989)

Indiana (1986)

Kansas (1989)

Kentucky (1987)

Maine (1988)

Maryland (1989)

Massachusetts (1989)

Michigan (1989)

Minnesota (1987)

Missouri (1986)

Nebraska (1988)

New Jersey (1986)

New York (1985)

Ohio (1990)

Pennsylvania (1989)

Rhode Island (1990)

South Carolina (1988)

South Dakota (1990)

Tennessee (1988)

Virginia (1988)

Washington (1990)

Wisconsin (1987)

Wyoming (1989)

${ }^{a}$ Source: Annotated State Codes, various states and years. 


\section{Table 3: Effects of BC Legislation on Wages: ${ }^{a}$}

Dependent Variable: Log Deflated Wage

$\mathrm{BC}^{*} \operatorname{After}_{t}^{B C}$
(1)

(2)

.010
(3)

(4)

(5)
(6)

(7)

$019^{* * * *}$

(.005)

$(.005) \quad(.005) \quad(.005)$

.004

$(.009)$

$-.284^{* * * *}$

(.009)

(.009)

$-.001$

(.004)

5658

$\begin{array}{lrrrrrrr}\text { Adjusted } R^{2} & .892 & .931 & .939 & .952 & .943 & .954 & .943 \\ \text { Sample Size } & \mathbf{9 8 5 2} & 9627 & 9305 & 9108 & 8988 & 8803 & 5658\end{array}$

\section{${ }^{a}$ Notes:}

1. Wages are defined as labor expenses divided by employment. $\mathrm{BC}$ is a dummy variable that equals 1 for a treatment state. After ${ }_{t}^{B C}$ is a dummy variable that equals 1 if the BC law has been passed by time t. Labor Expenses is in millions; Log Assets is the log of total start of year assets in millions; Log Employment is log of total employment in thousands; Log Sales is the log of net sales in millions; Log Market Value is the log market value of the firm in millions. Wages, assets, sales and market value are deflated using the CPI (IFS, 1996) (1983-1984=100).

2. Sample in columns (1) and (2) contains all the firm-year observations for which wage is computable. Sample in columns (3) and (4) contains all the firms for which the wage growth rate is always below $75 \%$ and always above $-44 \%$. Sample in columns (5) and (6) contains all the firms for which the wage growth rate is always below $50 \%$ and always above $-33 \%$. Column (7) reproduces column (4) but excludes the firms incorporated in Delaware.

3. All regressions also include year fixed effects and firm fixed effects.

4. Standard errors are in parenthesis.

5. ${ }^{*}$ denotes significance at the $10 \% ;^{* *}$ at the $5 \% ;^{* * *}$ at the $1 \% ;^{* * * *}$ at the $.1 \%$. 


\section{Table 4: Effects of $\mathrm{BC}$ Legislation: Robustness Checks ${ }^{a}$}

\section{Dependent Variable: Log Deflated Wage}

(1)
(2)
(3)
(4)
(5)

(6)

$\begin{array}{lcccccc}\text { BC*After }{ }_{t}^{B C} & .010^{* *} & .017^{* * *} & .016^{* * * *} & .015^{* * *} & .015^{* * *} & .015^{* * *} \\ & (.005) & (.005) & (.005) & (.005) & (.006) & (.005) \\ \text { Log Assets*YD } & \text { Yes } & \text { No } & \text { No } & \text { No } & \text { No } & \text { Yes } \\ \text { Log Employment*YD } & \text { No } & \text { Yes } & \text { No } & \text { No } & \text { No } & \text { Yes } \\ \text { Log Sales*YD } & \text { No } & \text { No } & \text { Yes } & \text { No } & \text { No } & \text { Yes } \\ \text { Log Market Value*YD } & \text { No } & \text { No } & \text { No } & \text { Yes } & \text { No } & \text { Yes } \\ \text { BC*Year } & \text { No } & \text { No } & \text { No } & \text { No } & \text { Yes } & \text { Yes } \\ \text { Adjusted } R^{2} & .954 & .953 & .953 & .953 & .952 & .959\end{array}$

a Notes:

1. Wages are defined as labor expenses divided by employment. $\mathrm{BC}$ is a dummy variable that equals 1 for a treatment state. After ${ }_{t}^{B C}$ is a dummy variable that equals 1 if the $\mathrm{BC}$ law has been passed by time $t$. Labor Expenses is in millions; Log Assets is the log of total start of year assets in millions; Log Employment is log of total employment in thousands; Log Sales is the log of net sales in millions; Log Market Value is the $\log$ market value of the firm in millions. Wages, assets, sales and market value are deflated using the CPI (IFS, 1996) (1983-1984=100).

2. Sample in columns (1) to (6) contains all the firms for which the wage growth rate is always below $75 \%$ and always above $-44 \%$. (Sample Size: 9108 ).

3. All regressions also include year fixed effects, firm fixed effects, Log Assets, Log Employment, Log Sales and Log Market Value.

4. Standard errors are in parenthesis.

5. ${ }^{* *}$ denotes significance at the $5 \% ;^{* * *}$ at the $1 \% ;^{* * * *}$ at the $.1 \%$. 
Table 5: Effects of BC Legislation:

Distribution of Effects ${ }^{a}$

Dependent Variable: Log Deflated Wage

$\begin{array}{lcccc} & (1) & (2) & (3) & (4) \\ \text { BC*After }_{t}^{B C} & .004 & .011^{* *} & .013^{* *} & .009^{*} \\ & (.005) & (.005) & (.005) & (.005) \\ \text { Log Assets*BC*After }{ }_{t}^{B C} & .009^{* * * *} & - & - & - \\ & (.003) & & & \\ \text { Log Employment*BC*After }{ }_{t}^{B C} & - & .004 & - & - \\ & & (.003) & & \\ \text { Log Sales*BC*After }{ }_{t}^{B C} & - & - & .004 & - \\ & & & (.003) & \\ \text { Log Market Value*BC*After }{ }_{t}^{B C} & - & - & - & .006^{* *} \\ & & & & (.003) \\ \text { Log Assets*BC } & .017^{* *} & - & - & - \\ & (.007) & & & \\ \text { Log Employment*BC } & - & .048^{* * *} & - & - \\ & & (.007) & & \\ \text { Log Sales*BC } & - & - & .023^{* * *} & - \\ & & & (.007) & \\ \text { Log Market Value*BC } & - & - & - & .012^{* * *} \\ & & & & (.004) \\ \text { Log Assets*YD } & \text { Yes } & \text { No } & \text { No } & \text { No } \\ \text { Log Employment*YD } & \text { No } & \text { Yes } & \text { No } & \text { No } \\ \text { Log Sales*YD } & \text { No } & \text { No } & \text { Yes } & \text { No } \\ \text { Log Market Value*YD } & \text { No } & \text { No } & \text { No } & \text { Yes } \\ & & & & \\ \text { Adjusted } R^{2} & .954 & .954 & .953 & .953 \\ & & & & \end{array}$

${ }^{a}$ Notes:

1. Wages are defined as labor expenses divided by employment. BC is a dummy variable that equals 1 for a treatment state. After ${ }_{t}^{B C}$ is a dummy variable that equals 1 if the $\mathrm{BC}$ law has been passed by time $t$. Labor Expenses is in millions; Log Assets is the log of total start of year assets in millions; Log Employment is log of total employment in thousands; Log Sales is the log of net sales in millions; Log Market Value is the log market value of the firm in millions. Wages, assets, sales and market value are deflated using the CPI (IFS, 1996) (1983-1984=100). Log Assets, Log Employment, Log Sales and Log Market Value have been demeaned.

2. Sample in all columns contains all the firms for which the wage growth rate is always below $75 \%$ and always above $-44 \%$. (Sample Size: 9108 ).

3. All regressions also include year fixed effects, firm fixed effects, Log Assets, Log Employment, Log Sales and Log Market Value.

4. Standard errors are in parenthesis.

5. " denotes significance at the $10 \% ;^{* * *}$ at the $5 \% ;^{* * *}$ at the $1 \% ;^{* * * *}$ at the $.1 \%$. 
Table 6: Effects of BC Legislation:

Dynamics $^{a}$

Dependent Variable: Log Deflated Wage

(1)

$\begin{array}{lccc}\text { BC }^{*} \text { Before }^{-1} & - & -.002 & .003 \\ & & (.006) & (.006) \\ \text { BC* }^{*} \text { Before }^{0} & - & .007 & -.005 \\ & & (.006) & (.006) \\ \text { BC }^{*} \text { After }^{1} & .003 & - & .003 \\ & (.006) & & (.006) \\ \text { BC }^{*} \text { After }^{2} & .006 & - & .006 \\ & (.006) & & (.007) \\ \text { BC }^{*} \text { After }^{>2} & .014^{* *} & - & .014^{* *} \\ & (.006) & & (.006) \\ \text { BC }^{*} \text { After }_{t}^{B C} & - & .014^{* * *} & - \\ & & (.006) & \\ {\text { Adjusted } R^{2}}^{2} & .952 & .952 & .952\end{array}$

a Notes:

1. Wages are defined as labor expenses divided by employment. BC is a dummy variable that equals 1 for a treatment state. $\operatorname{After}_{t}^{B C}$ is a dummy variable that equals 1 if the BC law has been passed by time $t$. Labor Expenses is in millions; Log Assets is the log of total start of year assets in millions; Log Employment is log of total employment in thousands; Log Sales is the log of net sales in millions; Log Market Value is the log market value of the firm in millions. Wages, assets, sales and market value are deflated using the CPI (IFS, 1996) $(1983-1984=100)$. Before $^{-1}$ is a dummy that equals 1 for the year before the law passed; Before ${ }^{0}$ is a dummy that equals 1 for the year the law passed; After ${ }^{1}$ is a dummy that equals 1 for the year after the law passed; After $^{2}$ is a dummy that equals 1 for two years after the law passed; After ${ }^{>2}$ is a dummy that equals 1 for strictly more than two years after the law passed.

2. Sample in all columns contains all the firms for which the wage growth rate is always below $75 \%$ and always above $-44 \%$. (Sample Size: 9108 ).

3. All regressions also include year fixed effects, firm fixed effects, Log Assets, Log Employment, Log Sales and Log Market Value.

4. Standard errors are in parenthesis.

5. ${ }^{* *}$ denotes significance at the $5 \% ;^{* * *}$ at the $1 \%$. 


\section{Appendix}

Table A: Effects of State Anti-Takeover
Legislation on Wages

Dependent Variable: Log Wage

(1) (2) (3) (4)

$\begin{array}{lcccc}\mathrm{BC}^{*} \mathrm{After}_{t}^{B C} & .011^{* *} & & & .011^{* *} \\ & (.005) & & & (.006) \\ \mathrm{FP}^{*} \operatorname{After}_{t}^{F P} & - & .003 & - & -.000 \\ & & (.005) & & (.006) \\ \mathrm{CSA}^{*} \operatorname{After}_{t}^{C S A} & - & - & .000 & -.000 \\ & & & (.006) & (.006)\end{array}$

$\begin{array}{lllll}\text { Adjusted } R^{2} & .939 & .939 & .939 & .939\end{array}$

${ }^{a}$ Notes:

1. Wages are defined as total expenses divided by employment. BC, FP and CSA are dummy variables that equal 1 for a state passing a $B C$ legislation, a FP legislation and a CSA legislation respectively. After ${ }_{t}^{B C}, \mathrm{After}_{t}^{F P}$ and $\mathrm{After}_{t}^{C S A}$ are dummy variables that equal 1 if the $\mathrm{BC}$ law, the FP law and the CSA law have respectively been passed by time $t$.

2. Sample in all columns contains all the firms for which the wage growth rate is always below $75 \%$ and always above $-44 \%$. (Sample Size: 9305 ).

3. All regressions also include year fixed effects and firm fixed effects.

4. Standard errors are in parenthesis.

5. ${ }^{* *}$ denotes significance at the $5 \%$. 